\title{
Specify Other KIT Mutation
}

National Cancer Institute

\section{Source}

National Cancer Institute. Specify Other KIT Mutation. NCI Thesaurus. Code C159255.

A request to enter the specific KIT mutation that was identified in the study but is not present in the form. 